\title{
PENGEMBANGAN PERANGKAT PEMBELAJARAN MATEMATIKA UNTUK SISWA SMK JURUSAN AKUNTANSI DI SLEMAN DENGAN PENDEKATAN PEMBELAJARAN KONTEKSTUAL
}

\author{
Suhartini ${ }^{1)}$, Rusgianto Heri Santoso ${ }^{2)}$ \\ Prodi Pendidikan Matematika PPs UNY ${ }^{1)}$, Universitas Negeri Yogyakarta ${ }^{2)}$ \\ suhartini86@gmail.com ${ }^{1)}$, santosa_rh@yahoo.co.id ${ }^{2)}$
}

\begin{abstract}
Abstrak
Tujuan penelitian ini adalah untuk menghasilkan perangkat pembelajaran matematika SMK kelas XI jurusan akuntansi dengan pendekatan pembelajaran kontekstual yang valid, praktis, dan efektif. Jenis penelitian adalah research \& development $(R \& D)$. Penelitian mengembangkan perangkat pembelajaran menggunakan model Borg \& Gall. Tahap-tahap yang dilalui sampai diperoleh perangkat pembelajaran matematika yang valid, praktis, dan efektif adalah studi pendahuluan, desain produk, uji ahli, uji coba terbatas dan uji coba lapangan. Subjek uji coba penelitian ini terdiri atas delapan siswa pada uji coba terbatas, 16 siswa pada uji coba lapangan dan dua guru kelas XI Jurusan Akuntansi di SMK 17 Seyegan. Instrumen penelitian yang digunakan adalah lembar validasi, lembar penilaian guru, lembar penilaian siswa, dan tes hasil belajar. Data yang diperoleh dianalisis secara deskriptif. Penelitian ini menghasilkan perangkat pembelajaran matematika yang meliputi rencana pelaksanaan pembelajaran (RPP), lembar kegiatan siswa (LKS), dan tes hasil belajar (THB) yang valid, praktis, dan efektif. Hasil penelitian menunjukkan bahwa masing-masing RPP, LKS, dan THB valid, praktis, dan efektif.
\end{abstract}

Kata kunci: pengembangan, perangkat pembelajaran, pendekatan pembelajaran kontekstual 


\section{PENDAHULUAN}

Sekolah menengah kejuruan (SMK) adalah jenjang pendidikan menengah vokasional pada pendidikan formal di Indonesia yang ditempuh setelah lulus dari sekolah menengah pertama (SMP) atau sederajat dalam waktu tiga tahun. SMK merupakan salah satu alternatif sekolah lanjutan selain sekolah menengah atas (SMA) atau madrasah aliyah (MA) bagi siswa yang ingin mendapatkan keahlian dalam suatu bidang setelah menempuh pendidikan di sekolah tersebut. Pembelajaran di SMK sangat berbeda dengan SMA pada umumnya, karena tujuan dan silabus yang berlaku juga berbeda. Tujuan SMK mulai diarahkan untuk memasuki lapangan kerja (terminal), dipekerjakan atau wiraswasta (Depdiknas, 2006, p.4).

Mata pelajaran yang diajarkan di SMK tidak berbeda dengan SMA pada umumnya. Selain mengajarkan ilmu-ilmu seperti yang diajarkan di SMA, SMK juga mengajarkan ilmu-ilmu yang sesuai dengan bidang keahlian yang ditekuni oleh siswa. Bidang keahlian yang dapat ditekuni yaitu pertanian, teknologi, industri dan keuangan, akibatnya mata pelajaran yang diajarkan dapat berfungsi membentuk kemampuan produktif yang dapat diterapkan pada lapangan pekerjaan yang sesuai dengan bidang keahlian masing-masing.

Mata pelajaran matematika merupakan salah satu mata pelajaran wajib yang diajarkan di SMK. Mata pelajaran matematika sebagai program adaptif yang merupakan mata pelajaran yang alokasi waktunya disesuaikan dengan kebutuhan program keahlian dan dapat diselenggarakan dalam blok waktu atau alternatif lain (BSNP, 2006b, pp.21-22).

Dalam kurikulum tingkat satuan pendidikan (KTSP) dikatakan bahwa prinsip kegiatan belajar mengajar yang memberdayakan potensi siswa diantaranya adalah kegiatan belajar yang berpusat pada siswa. Proses belajar mengajar (PBM) yang menempatkan siswa sebagai subjek belajar bisa mendorong siswa untuk mengembangkan potensinya secara optimal (Muslich, 2007, pp.48-49).

Pembelajaran yang berpusat pada siswa (student centered) menekankan pada aktivitas siswa. Siswa dibebaskan untuk beraktivitas sesuai dengan jalur-jalur yang telah ditetapkan. Untuk memperlancar kegiatan tersebut, maka digunakan perangkat pembelajaran yang terdiri dari rencana pelaksanaan pembelajaran (RPP), lembar kegiatan siswa (LKS), dan tes hasil belajar (THB).

Peraturan Pemerintah Nomor 19 tahun 2005 berkaitan dengan standar proses mengisyaratkan bahwa guru diharapkan mengembangkan perencanaan pembelajaran, yang kemudian dipertegas malalui peraturan menteri pendidikan nasional (permendiknas) nomor 41 tahun 2007 tentang standar proses, yang antara lain mengatur tentang perencanaan proses pembelajaran yang mensyaratkan bagi pendidik pada satuan pendidikan untuk mengembangkan RPP. Dalam penyusunan RPP perlu memperhatikan prinsipprinsip, antara lain: memperhatikan perbedaan individu peserta didik; mendorong partisipasi aktif peserta didik; mengembangkan budaya membaca dan menulis; memberikan umpan balik dan tindak lanjut; keterkaitan dan keterpaduan; dan menerapkan teknologi informasi dan komunikasi (BSNP, 2007a, pp.11-12).

Sementara itu, dari hasil observasi dan wawancara terhadap sepuluh guru matematika di SMK kelas XI jurusan Akuntansi di Sleman, apabila ditinjau dari penyusunan perangkat pembelajaran diperoleh bahwa tiga guru yang telah mengembangkan perangkat pembelajaran secara mandiri. Sedangkan tujuh guru lainnya menggunakan perangkat hasil men-download dari internet atau meng-copy file dari teman.

Apabila ditinjau dari komponen-komponen RPP, kesepuluh guru matematika telah memenuhi komponen-komponen tersebut. Akan tetapi, apabila ditinjau dari indikator pembelajaran, tidak semua guru merumuskan indikator dengan cara menurunkan Standar Kompetensi (SK) dan Kompetensi Dasar (KD), tujuh guru mengikuti contoh hasil download di internet maupun melihat buku pegangan. Adapun dilihat dari kegiatan pembelajaran yang dilakukan, dapat disimpulkan bahwa pemberian motivasi kepada siswa masih kurang, peran guru masih begitu dominan, kejelasan kegiatan pembelajaran yang berhubungan dengan metode pembelajaran yang digunakan masih kurang, alokasi waktu dalam kegiatan awal, kegiatan inti, dan kegiatan penutup belum jelas.

Apabila ditinjau dari sumber belajar yang digunakan, beberapa guru tidak melengkapi RPP dengan sumber belajar yang tercantum pada RPP tersebut. Sumber belajar yang digunakan oleh sebagian besar guru adalah buku referensi dari penerbit tertentu dan hanya tiga guru yang menggunakan LKS. Dua guru menyusun LKS sendiri sedangkan guru yang satunya lagi menggunakan LKS yang berasal dari penerbit ter- 
tentu. Ditinjau dari penilaian hasil pembelajaran, terdapat guru yang belum memperhatikan SK dan KD dalam melakukan penyusunan instrumen tes tersebut. Adapun penyusunan tes didasarkan pada materi yang telah diajarkan.

Dari hasil observasi dan wawancara menunjukkan bahwa perangkat pembelajaran yang disusun oleh beberapa guru matematika belum memenuhi prinsip-prinsip yang berlaku. Oleh karena itu, penulis termotivasi untuk mengembangkan perangkat pembelajaran untuk SMK jurusan Akuntansi.

Matematika sendiri merupakan suatu ilmu yang dapat mengembangkan kemampuan berfikir dan bernalar. Matematika sangat diperlukan baik untuk kehidupan sehari-hari maupun untuk menghadapi kemajuan IPTEK sehingga matematika perlu dibekalkan kepada setiap peserta didik sejak SD, bahkan sejak TK. Oleh sebab itu, matematika dianggap sebagai mata pelajaran yang sulit untuk dimengerti siswa.

Indikasi kesulitan belajar matematika ini bisa dilihat dari nilai hasil Ujian Nasional (UN) siswa yang kurang memuaskan. Nilai rata-rata hasil Ujian Nasional tahun pelajaran 2010/2011 SMK di Daerah Istimewa Yogyakarta (DIY) adalah 7,25, sementara nilai rata-rata mata pelajaran Matematika siswa SMK di Kabupaten Sleman merupakan peringkat kelima teren-dah dari lima kabupaten di DIY, adalah 7,00. Hal ini diperkuat dari hasil daftar kota/kabupaten jenjang SMK Ujian Nasional SMK tahun pelajaran 2010/2011 pada Tabel 1.

Tabel 1. Daftar Kota/Kabupaten Jenjang SMK Ujian Nasional SMK Akuntansi Tahun Pelajaran 2010/2011 Provinsi: 04 - DI Yogyakarta

\begin{tabular}{lccccccc}
\hline \multirow{2}{*}{ No } & \multirow{2}{*}{ Kode Kota } & \multirow{2}{*}{ Nama Kota/Kabupaten } & \multicolumn{4}{c}{ Mata Ujian } \\
\cline { 3 - 7 } & 02 & BIN & ING & MAT & KMP & TOT \\
\hline 1 & 05 & Bantul & 7,53 & 6,98 & 7,71 & 8,57 & 30,79 \\
2 & 03 & Gunungkidul & 7,38 & 6,66 & 7,34 & 8,66 & 30,04 \\
3 & 01 & Kulonprogo & 7,41 & 6,84 & 7,30 & 8,64 & 30,19 \\
4 & 04 & Kota Yogyakarta & 7,33 & 6,66 & 7,01 & 8,51 & 29,51 \\
5 & 99 & Sleman & 7,24 & 6,50 & 7,00 & 8,81 & 29,55 \\
6 & Provinsi & 7,37 & 6,71 & 7,25 & 8,64 & 29,97 \\
\hline
\end{tabular}

Sumber: (Puspendik, 2011)

Dikarenakan keterbatasan biaya, waktu dan tenaga peneliti maka penelitian ini khusus untuk standar kompetensi menerapkan konsep barisan dan deret dalam pemecahan masalah. Salah satu faktor yang dapat mempengaruhi rendahnya nilai rata-rata mata pelajaran Matematika siswa SMK di Kabupaten Sleman adalah adanya anggapan yang keliru dari guru-guru yang menganggap bahwa pengetahuan itu dapat dipindahkan secara utuh dari pikiran guru ke pikiran siswa. Dengan adanya anggapan tersebut, guru memfokuskan pembelajaran matematika pada upaya penuangan pengetahuan tentang matematika sebanyak mungkin.

Dalam rangka meningkatkan kualitas pembelajaran matematika, guru perlu memberikan kesempatan yang luas kepada siswa untuk menggali kemampuannya dalam mempelajari matematika, namun tetap dalam bimbingan guru. Salah satu solusi yang dapat dipertimbangkan adalah dengan penggunaan Lembar Kegiatan Siswa (LKS). Penggunaan LKS dalam kegiatan pembelajaran dapat mendorong siswa untuk mengolah sendiri bahan yang dipelajari atau bersama dengan temannya dalam suatu bentuk diskusi kelompok. LKS juga dapat memberi peluang bagi siswa untuk mengembangkan kreati-

vitasnya, walaupun masih ada peranan guru dalam memberikan arahan (Suhadi, 2007, p.5).

Dari hasil pengamatan di SMK kelas XI jurusan Akuntansi di Sleman, kebanyakan LKS yang dijumpai berisi ringkasan materi kemudian disusul dengan latihan-latihan sehingga keaktifan siswa dalam kegiatan pembelajaran belum optimal, dalam arti siswa tidak dituntut untuk membangun pengertian dan mengkontruksi pengetahuan dari materi yang dipelajari dengan kemampuan sendiri. Hal ini menjadi alasan peneliti perlunya dikembangkan LKS yang bisa membangun pengertian dan mengkontruksi pengetahuan siswa. Ditinjau dari penilaian hasil pembelajaran, terdapat guru yang belum memperhatikan SK dan KD dalam melakukan penyusunan instrumen tes tersebut. Adapun penyusunan tes didasarkan pada materi yang telah diajarkan.

Dalam perkembangan seperti sekarang ini, guru dituntut agar tugas dan perannya tidak lagi sebagai pemberi informasi, melainkan sebagai pendorong belajar agar siswa dapat mengkontruksi sendiri pengetahuannya melalui berbagai aktivitas dalam kegiatan pembelajaran. Oleh sebab itu, guru diharapkan dapat memberikan suatu alternatif model pembelajaran yang 
menarik dan dapat menunjang tumbuhnya kegiatan pembelajaran yang berpusat pada siswa. Dari hasil pengamatan kebanyakan guru belum mengaitkan materi pembelajaran dengan kehidupan sehari-hari dan belum membiasakan masyarakat belajar (learning community) misalnya dengan belajar kelompok. Hal ini menjadi alasan bagi peneliti untuk mengembangkan perangkat pembelajaran dengan pendekatan pembelajaran kontekstual.

Salah satu ciri pendekatan kontekstual adalah pembelajaran berpusat pada siswa. Pembelajaran dilaksanakan dengan memperhatikan potensi siswa, sarana pembelajaran, situasi dan kondisi, serta memperhatikan tujuan pembelajaran yang ingin dicapai. Menurut Sanjaya (2011, p.255) pendekatan kontekstual adalah suatu strategi pembelajaran yang menekankan kepada proses keterlibatan siswa secara penuh untuk dapat menemukan materi yang dipelajari dan menghubungkannya dengan situasi kehidupan nyata sehingga mendorong siswa untuk dapat menerapkannya dalam kehidupan mereka. Melalui penerapan materi dalam kehidupan seharihari, siswa akan merasakan pentingnya belajar dan akan mem-peroleh makna yang mendalam terhadap apa yang dipelajarinya sehingga materi tersebut akan tertanam erat dalam memori siswa.

Salah satu materi matematika yang memiliki aplikasi yang sangat luas dalam kehi-dupan sehari-hari dan dipelajari pada siswa SMK kelas XI jurusan Akuntansi semester ganjil adalah materi barisan dan deret. Barisan dan deret yang disajikan meliputi pengertian tentang barisan dan deret, barisan dan deret aritmetika serta barisan dan deret geometri. Perhitungan bunga bank, penyusutan nilai barang, merupakan salah satu contoh penerapan dari barisan dan deret dalam bidang ekonomi dan merupakan materi yang ditempuh berikutnya oleh siswa SMK kelas XI jurusan Akuntansi semester ganjil. Akan tetapi, sampai saat ini kurang adanya sumber atau media belajar materi barisan dan deret yang mendorong siswa untuk menemukan dan mengaplikasikan konsep barisan dan deret dalam menyelesaikan masalah-masalah yang berkaitan dengan kehidupan sehari-hari.

Perangkat pembelajaran yang diterapkan saat ini sebenarnya belum cukup membantu meningkatkan pemahaman siswa. Hal ini disebabkan karena skenario pembelajaran yang disusun masih menggunakan sistem pembelajaran yang berpusat pada guru, sehingga siswa kurang berperan aktif dalam kegiatan belajar.
Berdasarkan permasalahan tersebut, maka perlu dilakukan pembelajaran yang berpusat pada siswa dan melibatkan siswa aktif sehingga mereka mengetahui apa yang dipelajari dan manfaatnya dalam kehidupan sehari-hari. untuk keperluan tersebut perlu dikembangkan perangkat pembelajaran.

Oleh karena itu muncul pertanyaan, bagaimana pengembangan yang dilakukan untuk menghasilkan perangkat pembelajaran matematika untuk SMK kelas XI jurusan Akuntansi yang baik dan layak untuk digunakan, yaitu memenuhi kriteria valid, praktis, dan efektif? Dan seberapa valid, praktis, dan efektif perangkat pembelajaran matematika untuk SMK kelas XI jurusan Akuntansi yang dihasilkan?

Penelitian ini dilakukan dengan tujuan menghasilkan perangkat pembelajaran matematika dengan pendekatan pembelajaran kontekstual yang valid, praktis, dan efektif di SMK kelas XI jurusan akuntansi.

Hasil penelitian ini dapat dijadikan sebagai modal dalam pengembangan perangkat pembelajaran matematika yang menggunakan pendekatan pembelajaran kontekstual di SMK pada kompetensi yang lain. Selain itu digunakan untuk pembelajaran di kelas sehingga tujuan pembelajaran matematika yang diharapkan dapat tercapai.

\section{METODE PENELITIAN}

\section{Model Pengembangan}

Penelitian ini merupakan penelitian pengembangan atau development research. Pada penelitian ini yang dilakukan adalah mengembangkan perangkat pembelajaran matematika untuk siswa SMK kelas XI semester ganjil jurusan Akuntansi berdasarkan pendekatan pembelajaran kontekstual, khususnya untuk standar kompetensi menerapkan konsep barisan dan deret dalam pemecahan masalah. Perangkat pembelajaran yang dikembangkan meliputi Rencana Pelaksanaan Pembelajaran (RPP), Lembar Kegiatan Siswa (LKS), dan Tes Hasil Belajar (THB).

Model pengembangan yang digunakan dalam penelitian ini adalah modifikasi dari model rancangan pengembangan dari Borg \& Gall. Model Borg \& Gall adalah salah satu model penelitian dan pengembangan yang dikenal dan dipakai secara luas dalam bidang pendidikan. Untuk mengetahui kualitas produk yang dikembangkan mengacu kepada 3 kategori produk yang dikemukakan oleh Nieveen (1999, p.176) 
yaitu aspek kualitas yang dilihat dari validitas, kepraktisan, dan keefektifan.

\section{Prosedur Pengembangan}

Prosedur pengembangan diadaptasi dari model pengembangan menurut Borg \& Gall. Dalam penelitian ini, peneliti merancang dan memodifikasi model pengembangan tersebut ke dalam 3 tahap, yaitu:

\section{Tahap Studi Pendahuluan}

Tahap studi pendahuluan terdiri dari studi pustaka dan prasurvei lapangan. Prasurvei lapangan dilakukan dengan tujuan untuk memperoleh data tentang perangkat pembelajaran yang digunakan oleh guru, strategi pembelajaran yang digunakan dan kompetensi matematika yang dimiliki siswa SMK. Prasurvei lapangan ini dilakukan dengan observasi dengan guru, dimana observasi yang dilakukan yaitu pengamatan waktu guru mengajar. Observasi di kelas ini bertujuan untuk mengetahui proses yang dilakukan guru maupun melihat keefektifan dari siswa dalam mengikuti proses pembelajaran, serta perangkat pembelajaran yang digunakan guru dalam pembelajaran. Kegiatan prasurvei lapangan dilaksanakan pada tanggal 21-26 November 2011. Prasurvei lapangan dilakukan dengan melakukan penyebaran angket terhadap sepuluh guru matematika SMK kelas XI jurusan Akuntasi di Kabupaten Sleman. Data angket menunjukkan bahwa tiga orang guru yang menyusun RPP dengan menggunakan prinsip-prinsip penyusunan RPP yang berlaku dengan menggunakan pendekatan pembelajaran kontekstual, tiga orang guru yang menggunakan LKS dengan pendekatan pembelajaran kontekstual, satu orang guru yang menyusun THB berdasarkan SK dan KD dengan pendekatan pembelajaran kontekstual. Hasil prasurvei tersebut menujukkan bahwa masih kurangnya pengembangan RPP, LKS, dan THB berdasarkan pendekatan pembelajaran kontekstual.

Pada tahap studi pustaka, melakukan kajian tentang konsep atau materi yang berkenaan dengan barisan dan deret dengan pendekatan pembelajaran kontekstual berupa perangkat pembelajaran yang akan dikembangkan. Kajian yang dilakukan meliputi kajian terhadap kurikulum tingkat satuan pendidikan tahun 2006 untuk mata pelajaran matematika, standar kompetensi, kompetensi dasar maupun materi pelajaran. Selain itu juga dilakukan kajian terhadap hasilhasil penelitian yang berkenaan dengan pende- katan pembelajaran kontekstual dan kajian pustaka pada materi pokok barisan dan deret.

\section{Tahap Desain Produk}

Berdasarkan pada studi kepustakaan mengenai dasar-dasar teori dan konsep pembelajaran serta prasurvei di lapangan, maka peneliti menyusun draf awal perangkat pembelajaran. Perangkat pembelajaran berdasarkan pendekatan pembelajaran kontekstual yang dikembangkan yaitu RPP, LKS, dan THB. Produk hasil dari draf awal dinamakan produk draf 1 .

\section{Tahap pengembangan dan Evaluasi}

Draf 1 yang telah dihasilkan kemudian diujicobakan untuk pengembangan lebih lanjut. Uji coba yang dilakukan meliputi tiga tahap yaitu uji ahli, uji coba terbatas, dan uji coba lapangan. Uji coba ahli dilakukan untuk menguji kevalidan produk berupa perangkat pembelajaran berdasarkan pendekatan pembelajaran kontekstual pada materi pokok barisan dan deret. Hasil validasi dijadikan dasar untuk mengevaluasi dan merevisi draf 1 perangkat pembelajaran sebelum diujicobakan. Pada tahap uji coba terbatas dan uji coba lapangan dilakukan pembelajaran dengan menggunakan perangkat pembelajaran yang dikembangkan dan dilakukan pengamatan. Hasil uji coba kemudian dijadikan dasar untuk evaluasi dan perbaikan sehingga dihasilkan produk akhir.

\section{Instrumen Penelitian}

Adapun produk yang dihasilkan dari pengembangan yakni; perangkat pembelajaran matematika berupa rencana Pelaksanaan PemBelajaran (RPP), Lembar Kegiatan Siswa (LKS), dan Tes Hasil Belajar (THB). Instrumen penilaian yang digunakan dalam penelitian ini dapat dilihat pada tabel berikut:

Tabel 2. Instrumen Penelitian

\begin{tabular}{cl}
\hline \multirow{2}{*}{ Kualitas } & \multicolumn{1}{c}{ Instrumen yang Digunakan } \\
\cline { 2 - 2 } & \multicolumn{1}{c}{\begin{tabular}{c}
\multicolumn{1}{c}{ Perangkat Pembelajaran } \\
Matematika
\end{tabular}} \\
\hline Kevalidan & - Instrumen penilaian kevalidan RPP \\
& - Instrumen penilaian kevalidan LKS \\
Kepraktisan & - Instrumen penilaian kevalidan THB \\
& - Lembar penilaian kepraktisan \\
& pembelajaran dari guru \\
& - Lembar penilaian kepraktisan \\
& pembelajaran dari siswa \\
Keefektifan & - THB \\
\hline
\end{tabular}




\section{Subjek Penelitian}

Subjek uji coba dalam penelitian ini adalah siswa kelas XI SMK Seyegan jurusan Akuntansi, serta guru Matematika kelas XI SMK Seyegan. Sebaran jumlah subjek uji disajikan pada tabel 3.

Tabel 3. Sebaran Subjek Uji Coba

\begin{tabular}{cccc}
\hline Jenis & \multicolumn{2}{c}{ Jumlah Subjek Uji Coba } & \multirow{2}{*}{ Jumlah } \\
\cline { 2 - 3 } Subjek & Terbatas & Lapangan & \\
\hline Siswa & 8 orang & 16 orang & 24 orang \\
Guru & 1 orang & 1 orang & 2 orang \\
\hline
\end{tabular}

\section{Tempat dan Waktu Penelitian}

Penelitian yang berupa uji coba perangkat pembelajaran yang dihasilkan dilakukan pada satu kelas XI SMK 17 Seyegan jurusan Akuntansi tahun ajaran 2011/2012. Uji coba dilaksanakan pada akhir bulan Agustus sampai dengan akhir September 2012, dengan urutan kegiatan sebagai berikut.

Tabel 4. Kegiatan Penelitian

\begin{tabular}{llc}
\hline No & \multicolumn{1}{c}{ Kegiatan } & $\begin{array}{c}\text { Waktu } \\
\text { Pelaksanaan }\end{array}$ \\
\hline 1 & Analisis Kebutuhan dan & Nov.-Des 2011 \\
& Perumusan Tujuan & Jan-Febr 2012 \\
2 & Penyusunan Produk & Febr-Maret 2012 \\
3 & Uji ahli/validasi ahli & April-Juni 2012 \\
4 & Revisi I & Akhir Agust 2012 \\
5 & Uji coba Terbatas & September 2012 \\
6 & Uji coba Lapangan & \\
\hline
\end{tabular}

\section{Jenis Data}

Jenis data dalam penelitian ini berupa data kualitatif dan kuantitatif. Data kualitatif diperoleh pada penelitian berupa saran atau komentar dari validator. Data kuantitatif diperoleh dari skor tanggapan validator terhadap perangkat pembelajaran, skor lembar penilaian guru, skor lembar penilaian siswa, dan tes hasil belajar.

\section{Teknik Analisis Data}

Analisis data dalam penelitian ini bertujuan untuk menjawab pertanyaan penelitian. Data yang berupa komentar, saran, revisi, dan hasil observasi selama proses uji coba dianalisis secara deskriptif kualitatif dan disimpulkan sebagai masukan untuk merevisi produk yang dikembangkan. Sedangkan, data yang berupa skor tanggapan ahli, skor penilaian guru, skor penilaian siswa dan THB.

Secara umum teknik analisis dari data tersebut yaitu data yang didapatkan dikelompokkan berdasarkan kualifikasi produk yang akan dinilai. Dilakukan perhitungan rata-rata atas data yang telah dilakukan pengelompokan. Dari ratarata yang didapatkan kemudian diubah ke dalam kriteria kualitatif dengan ketentuan seperti pada tabel 5. Dari tabel 5 yang diadaptasi dari Direktorat Pembinaan SMA (2010, pp.59-60) dapat diketahui kualitas produk yang dikembangkan. Adapun tabel kriteria penilaian skala likert yaitu sebagai berikut.

Tabel 5. Kriteria Penilaian Skala Likert

\begin{tabular}{cc}
\hline Interval & Kriteria \\
\hline$M_{\mathrm{i}}+1_{3} 8 S D i<\bar{M}$ & Sangat baik \\
$M_{\mathrm{i}}+0,6 S D i<\bar{M} \leq M_{\mathrm{i}}+1,8 S D i$ & Baik \\
$M_{\mathrm{i}}-0,6 S D i<\bar{M} \leq M_{\mathrm{i}}+0,6 S D i$ & Cukup \\
$M_{\mathrm{i}}-1_{3} 8 S D i<\bar{M} \leq M_{\mathrm{i}}-0,6 S D i$ & Kurang \\
$\bar{M} \leq M_{\mathrm{i}}-1_{2} 8 S D i$ & Sangat Kurang \\
\hline
\end{tabular}

Keterangan:

$\bar{M} \quad=$ Rata-rata akhir

$M_{i} \quad=$ Rata-rata ideal $=1 / 2$ (skor maksimun ideal + skor minimum ideal)

$S D i=$ Standar deviasi ideal $=\frac{1}{6}($ skor maksimun ideal-skor minimum ideal)

Skor maks ideal $=\Sigma$ butir kriteria $\times$ skor tertinggi

Skor min ideal $=\Sigma$ butir kriteria $\times$ skor terendah

\section{HASIL PENELITIAN DAN PEMBAHASAN}

\section{Validitas Produk}

Untuk menjaring skor kevalidan digunakan instrumen kevalidan. Seluruh skor pada lembar penilaian instrumen yang telah diisi oleh validator dijumlahkan menjadi skor aktual validasi. Perangkat dapat digunakan jika skor aktual berada pada kategori minimal valid, yakni; (1) RPP > 136, (2) LKS > 156,4, dan (3) THB > 47,6. Skor hasil validasi dapat dilihat pada tabel 6 berikut:

Tabel 6. Hasil Analisis Data Validasi

\begin{tabular}{ccccc}
\hline \multirow{2}{*}{$\begin{array}{c}\text { Nama } \\
\text { Sumber }\end{array}$} & RPP & LKS & THB & $\begin{array}{c}\text { Total } \\
\text { skor } \\
\text { produk }\end{array}$ \\
\cline { 2 - 5 } & & 161 & 67 & 390 \\
V 1 & 162 & 161 & 392 \\
V 2 & 158 & 179 & 55 & 385 \\
V 3 & 160 & 172 & 53 & 1167 \\
Skor total & 480 & 512 & 175 & 389 \\
Rata-rata & 160 & 170,67 & 58,33 & valid \\
skor total & vategori & valid & valid & valid \\
Kategroduk yang Divalidasi \\
\hline
\end{tabular}

Data pada tabel 6 menunjukkan bahwa penilaian dari para ahli secara keseluruhan 
perangkat yang dikembangkan dinyatakan memenuhi kriteria valid.

\section{Kepraktisan dan Keefektifan Produk}

Kepraktisan Produk

Seluruh skor pada lembar penilaian instrumen yang telah diisi oleh guru dijumlahkan menjadi skor aktual kepraktisan dari guru (XKG). Perangkat pembelajaran yang dikembangkan dikatakan telah memenuhi kriteria kepraktisan yaitu jika kategori minimal tingkat kepraktisan yang dicapai adalah mudah dilaksanakan, yakni; (1) RPP > 40,8, (2) LKS > 44,2, dan (3) THB > 37,4. Skor analisis hasil penilaian guru atas produk yang dikembangkan dapat dilihat pada tabel 7 berikut:
Tabel 7. Analisis Skor Penilaian Guru

\begin{tabular}{cccc}
\hline Produk & $\begin{array}{c}\text { Skor } \\
\text { Aktual }\end{array}$ & $\begin{array}{c}\text { Rata- } \\
\text { rata Skor }\end{array}$ & Kategori \\
\hline RPP & 50 & 50 & Mudah Dilaksanakan \\
LKS & 54 & 54 & Mudah Dilaksanakan \\
THB & 44 & 44 & Mudah Dilaksanakan \\
\hline
\end{tabular}

Berdasarkan tabel 7 dapat diketahui bahwa rata-rata skor tiap produk berada pada kategori mudah dilaksanakan. Hal ini berarti bahwa produk praktis untuk digunakan.

Selain dari hasil penilaian guru, hasil penilaian siswa menunjukkan bahwa skor aktual kepraktisan dari siswa (XKS), perangkat pembelajaran yang dikembangkan memiliki kriteria praktis jika $80 \%$ siswa memberi penilaian yang menunjukkan XKS berada pada kategori minimal baik, dimana XKS > 51. Analisis hasil penilaian siswa terhadap perangkat pembelajaran yang dikembangkan dapat dilihat pada tabel 8 berikut ini:

Tabel 8. Analisis Skor Penilaian Siswa

\begin{tabular}{ccccc}
\hline Kelas & $\begin{array}{c}\text { Rata-rata } \\
\text { skor }\end{array}$ & $\begin{array}{c}\text { Jumlah } \\
\text { siswa }\end{array}$ & $\begin{array}{c}\text { Jumlah siswa yang memberi } \\
\text { skor }>\mathbf{5 1}\end{array}$ & $\begin{array}{c}\text { Presentase siswa yang menilai } \\
\text { minimal "baik" }\end{array}$ \\
\hline Akuntansi & 55,875 & 16 & 14 & $87,5 \%$ \\
\hline
\end{tabular}

Berdasarkan tabel 8, menunjukkan bahwa persentase siswa dari kelas yang menilai perangkat pembelajaran matematika pada kategori minimal "baik" melebihi $80 \%$ yaitu sebesar $87,5 \%$, sehingga dapat dikatakan perangkat pembelajaran matematika yang dihasilkan sudah mencapai kriteria praktis.

\section{Kepraktisan Produk}

Hasil belajar dikatakan efektif/tuntas secara individual jika mencapai Kriteria Ketuntasan Minimal (KKM) yang ditetapkan sekolah yaitu 75, sedangkan keefektifan klasikal tercapai jika paling sedikit $75 \%$ siswa subjek uji coba mencapai kriteria ketuntasan individual. Berdasarkan data hasil belajar yang diperoleh oleh siswa hasil belajar dari kelas akuntansi diperoleh hasil analisis seperti pada tabel berikut.

Tabel 9. Analisis data hasil belajar

\begin{tabular}{cccc}
\hline Kelas & $\begin{array}{c}\text { Jumlah } \\
\text { siswa }\end{array}$ & $\begin{array}{c}\text { Jumlah } \\
\text { siswa yang } \\
\text { tuntas }\end{array}$ & $\begin{array}{c}\text { Presentasi } \\
\text { siswa yang } \\
\text { tuntas }\end{array}$ \\
\hline Akuntansi & 16 & 14 & $87,5 \%$ \\
\hline
\end{tabular}

Dari analisis tersebut, maka diperoleh bahwa pada kelas akuntansi, presentase siswa tuntas atau hasil tesnya telah mencapai nilai Kriteria Ketuntasan Minimal (KKM), yaitu 75 lebih dari $75 \%$, yaitu sebesar $87,5 \%$. Oleh karena itu, dikatakan hasil tes belajar dari kelas tersebut telah mencapai kriteria ketuntasan individu maupun klasikal, yaitu banyaknya siswa yang tuntas mencapai $75 \%$. Jadi, perangkat pembelajaran matematika pada materi barisan dan deret yang dihasilkan telah memenuhi kriteria efektif.

\section{SIMPULAN DAN SARAN}

\section{Simpulan tentang Produk}

Penelitian telah mengembangkan suatu produk yaitu perangkat pembelajaran matematika menggunakan pendekatan pembelajaran kontekstual di SMK kelas XI jurusan akuntansi yang dikembangkan dengan melalui tahapantahapan: studi pendahuluan, desain/pengembangan produk, uji ahli, uji coba terbatas dan uji coba lapangan. Hasil pengembangan adalah produk berupa perangkat pembelajaran matematika menggunakan pendekatan pembelajaran kontekstual di SMK kelas XI jurusan akuntansi, yang meliputi Rencana Pelaksanaan Pembelajaran (RPP), Lembar Kegiatan Siswa (LKS), dan 
Tes Hasil Belajar (THB) yang valid dan layak untuk digunakan.

Perangkat pembelajaran matematika menggunakan pendekatan pembelajaran kontekstual di SMK kelas XI jurusan Akuntansi yang dihasilkan, yang terdiri atas RPP, LKS, dan THB masing-masing termasuk ke dalam kategori valid.

Perangkat pembelajaran matematika menggunakan pendekatan pembelajaran kontekstual di SMK kelas XI jurusan Akuntansi yang dihasilkan, yang terdiri atas RPP, dan LKS masing-masing termasuk ke dalam kategori praktis.

Perangkat pembelajaran matematika menggunakan pendekatan pembelajaran kontekstual di SMK kelas XI jurusan Akuntansi yang dihasilkan, yang terdiri atas RPP, dan LKS efektif dilihat dari hasil tes belajar siswa.

\section{Keterbatasan Penelitian}

Beberapa keterbatasan yang terdapat pada penelitian ini adalah sebagai berikut:

Pengembangan perangkat pembelajaran matematika untuk SMK kelas XI jurusan Akuntansi hanya dilakukan untuk materi barisan dan deret saja karena keterbatasan waktu dan biaya yang dimiliki oleh peneliti.

Uji coba produk hanya dilakukan pada satu sekolah saja. Hal ini disebabkan masih terbatasnya jumlah sekolah-sekolah yang menjadi tempat sasaran produk pengembangan.

\section{Saran Pemanfaatan, Diseminasi, dan pengembangan Produk Lebih Lanjut.}

Adapun saran pemanfaatan, diseminasi, dan pengembangan produk lebih lanjut adalah:

Perangkat pembelajaran matematika yang terdiri dari RPP, LKS, dan THB pada materi barisan dan deret yang telah dihasilkan telah teruji kelayakannya, yaitu telah memenuhi kriteria valid, praktis, dan efektif, sehingga valid dan layak digunakan dan dapat dimanfaatkan untuk pembelajaran di kelas-kelas jurusan Akuntansi di SMK lainnya.

Produk yang dikembangkan dapat dijadikan sebagai contoh perangkat pembelajaran matematika yang dapat disebarluaskan serta menjadi bahan masukan para guru dalam menyusun perangkat pembelajaran matematika untuk pembelajaran di kelas.

Pengembangan perangkat pembelajaran matematika hanya dilakukan untuk materi baris- an dan deret, maka disarankan untuk peneliti lain untuk mengembangkan perangkat pembelajaran matematika untuk materi lainnya.

\section{DAFTAR PUSTAKA}

Badan Standar Nasional Pendidikan. (2007a). Peraturan menteri pendidikan nomor 41 tahun 2007 tentang standar proses. Jakarta: Depdiknas.

Badan Standar Nasional Pendidikan. (2006b). Standar isi untuk satuan pendidikan dasar dan menengah (Standar kompetensi dan kompetensi dasar SMK/MAK). Jakarta: BSNP

Depdiknas. (2006). Kurikulum tingkat satuan pendidikan SMK. Jakarta: Direktorat Pembinaan Sekolah Menengah Kejuruan Subdit Pembelajaran.

Masnur Muslich. (2007). KTSP (Kurikulum tingkat satuan pendidikan) dasar pemahaman dan pengembangan. Jakarta: Bumi Aksara

Nieveen, N. (1999). Prototyping to reach product quality. London: Kluwer Academic Publisher. Dalam Akker, J., Branch, R.M., Gustafson, K., et al. (Eds.), Design approaches and tools in education and training (pp. 126-135). Dordrecht, The Netherlands: Kluwer Academic Publishers.

Peraturan Pemerintah RI Nomor 19 Tahun 2005 tentang standar nasional. Diakses tanggal 12 Juli 2011, dari Error! Hyperlink reference not valid.

Pusat Penelitian Pendidikan. (2011). Laporan hasil dan statistik nilai ujian nasional tahun pelajaran 2010/2011. Departemen Pendidikan Nasional

Sanjaya, Wina. (2011). Strategi pembelajaran berorientasi standar proses pendidikan. Jakarta: Kencana Prenada Media.

Suhadi. (2007). Penyusunan perangkat pembelajaran dalam kegiatan lesson study. Diakses tanggal 13 September 2011 dari http://suhadinet.wordpress.com/2008/05/ 28/penyusunan-perangkat-perangkatpembelajaran-dalam-kegiatan-lessonstudy/. 